\title{
New Glycosides from the Rhizomes of Tacca chantrieri
}

\author{
Akihito Yokosuka and Yoshihiro MIMAKI* \\ Laboratory of Medicinal Pharmacognosy, Tokyo University of Pharmacy and Life Sciences, School of Pharmacy; 1432-1 \\ Horinouchi, Hachioji, Tokyo 192-0392, Japan. Received September 13, 2006; accepted November 8, 2006
}

Five new glycosides, which are classified into two bisdesmosidic pseudofurostanol glycosides $(1,2)$, two new ergostanol glycosides $(3,4)$, and a new phenolic glycoside (5), were isolated from the rhizomes of Tacca chantrieri. The structures of $1-5$ were determined on the basis of extensive spectroscopic analysis, including that of twodimensional (2D) NMR data, as well as hydrolytic cleavage followed by spectroscopic and chromatographic analyses.

Key words Taccaceae; Tacca chantrieri; glycoside; pseudofurostanol glycoside; ergostanol glycoside; phenolic glycoside

Tacca chantrieri ANDRÉ is a perennial plant belonging to the family Taccaceae and is indigenous to southeast region of the People's Republic of China. A decoction prepared from the rhizomes of $T$. chantrieri has long been used in traditional Chinese medicine for the treatment of gastric ulcer, enteritis, and hepatitis. ${ }^{1)}$ Our previous chemical studies on the rhizomes of $T$. chantrieri led to the isolation of diarylheptanoids, diarylheptanoid glucosides, and steroidal glycosides such as spirostanol, furostanol, pseudofurostanol, pregnane, and withanolide glycosides, some of which showed cytotoxic activities against cultured tumor cells. ${ }^{2-8)}$ Further phytochemical analysis of $T$. chantrieri rhizomes, with particular inference to the glycoside constituents, has resulted in the isolation of five new glycosides, which are classified into two bisdesmosidic pseudofurostanol glycosides $(\mathbf{1}, \mathbf{2})$, two new ergostanol glycosides $(\mathbf{3}, \mathbf{4})$, and a new phenolic glycoside (5). This paper reports the structural determination of the new glycosides, which was carried out on the basis of exten- sive spectroscopic analysis, including that of two-dimensional (2D) NMR data, as well as hydrolytic cleavage followed by spectroscopic and chromatographic analyses.

The rhizomes of Tacca chantrieri (dry weight of $7.3 \mathrm{~kg}$ ) were extracted with hot $\mathrm{MeOH}$ twice. After removal of the solvent, the extract was passed through a porous-polymer polystyrene resin (Diaion HP-20) column, successively eluted with $\mathrm{MeOH}-\mathrm{H}_{2} \mathrm{O}$ gradients, EtOH, and EtOAc. The $\mathrm{MeOH}$ eluate portion was subjected to silica gel and octadecylsilanized (ODS) silica gel column chromatography to afford compounds $\mathbf{1}-\mathbf{5}$.

Compound 1 was isolated as an amorphous solid. The high-resolution electrospray-ionization time of flight mass spectrum (HR-ESI-TOF-MS) of $\mathbf{1}$ exhibited an accurate $[\mathrm{M}+\mathrm{Na}]^{+}$ion at $m / z 1231.5692$, allowing the molecular formula of 1 to be assigned as $\mathrm{C}_{57} \mathrm{H}_{92} \mathrm{O}_{27}$, which was confirmed by analysis of the ${ }^{13} \mathrm{C}$-NMR sepctrum combined with distortionless enhancement by polarization transfer (DEPT) spec-
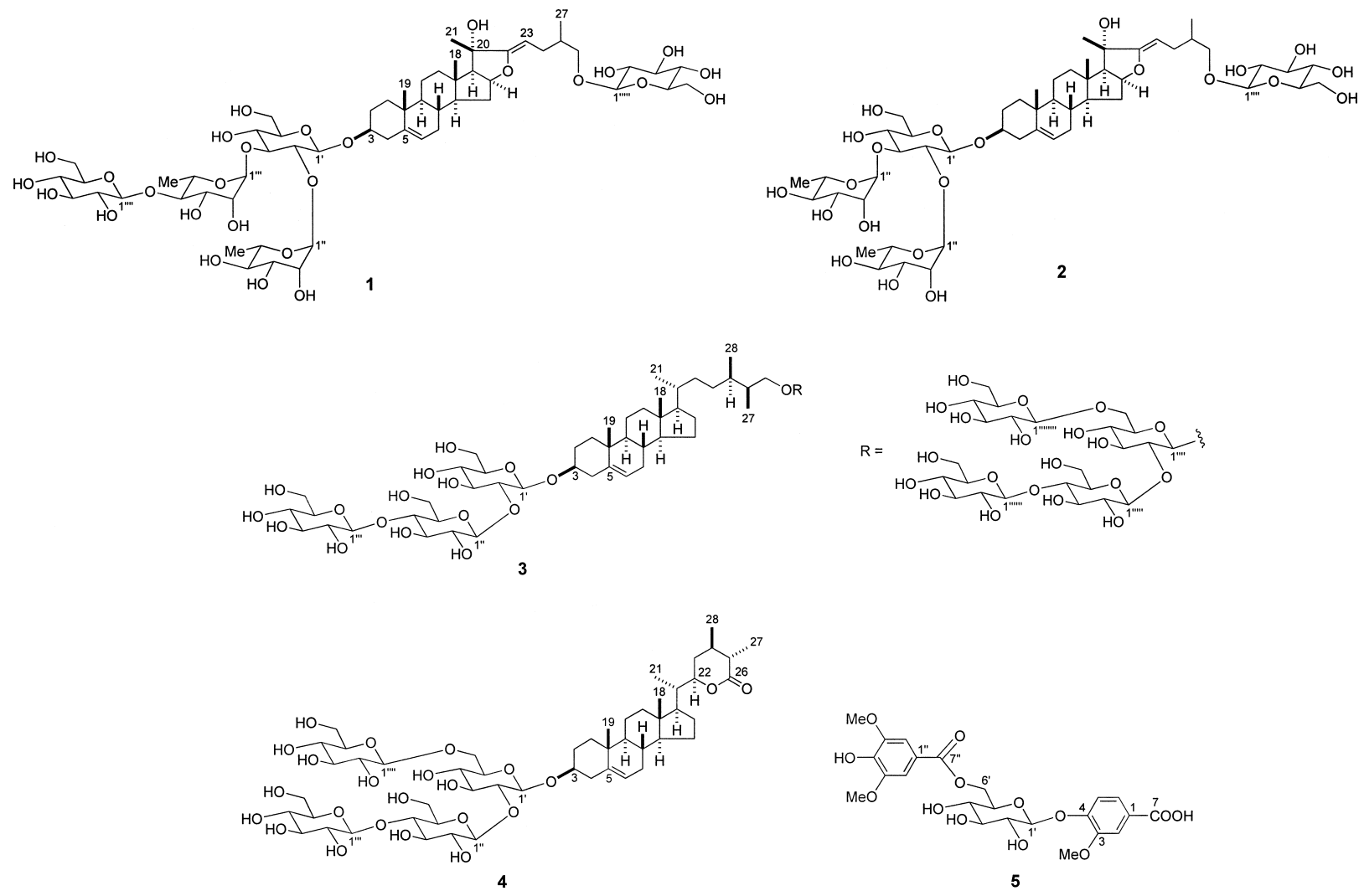

* To whom correspondence should be addressed. e-mail: mimakiy@ps.toyaku.ac.jp 
tral data. The ${ }^{1} \mathrm{H}-\mathrm{NMR}$ spectrum of $\mathbf{1}$ contained signals for four steroidal methyl groups at $\delta 1.73$ (s), 1.07 (d, $J=6.8 \mathrm{~Hz}), 1.06(\mathrm{~s})$, and $0.92(\mathrm{~s})$, and two olefinic protons at $\delta 5.32(\mathrm{brd}, J=4.4 \mathrm{~Hz}$ ) and $4.53(\mathrm{t}, J=6.9 \mathrm{~Hz}$ ), as well as signals for five anomeric protons at $\delta 5.82$ (brs), 5.76 (brs), 5.25 (d, $J=7.8 \mathrm{~Hz}), 4.90(\mathrm{~d}, J=7.6 \mathrm{~Hz}$ ), and 4.85 (d, $J=$ $7.7 \mathrm{~Hz}$ ). Acid hydrolysis of 1 with $1.0 \mathrm{M} \mathrm{HCl}$ in dioxane- $\mathrm{H}_{2} \mathrm{O}$ ( $1: 1)$ resulted in the production of D-glucose and L-rhamnose as the carbohydrate components, while the labile genuine sapogenin was decomposed under acidic conditions. Identification of the monosaccharides, including their absolute configurations, was carried out by direct HPLC analysis of the hydrolysate, using a combination of refractive index (RI) and optical rotation $(\mathrm{OR})$ detectors.

Analysis of the ${ }^{1} \mathrm{H}$ - and ${ }^{13} \mathrm{C}-\mathrm{NMR}$ spectra of $\mathbf{1}$ revealed that the structure of the ring $\mathrm{A}-\mathrm{D}$ portion $(\mathrm{C}-1-\mathrm{C}-19)$ was identical to that of the usual furost-5-en-3 $\beta$-ol derivatives. ${ }^{5)}$ However, significant differences were recognized in the signals from the ring $\mathrm{E}$ part and the side chain moiety (C-20C-27), where a tertiary hydroxy group $\left[\delta_{\mathrm{C}} 76.7(\mathrm{C})\right]$ and an oxygen-bearing trisubstituted olefinic group $\left[\delta_{\mathrm{C}} 163.7(-\mathrm{O}-\right.$ $\left.\mathrm{C}=) ; \delta_{\mathrm{C}} 91.4(=\mathrm{CH}) / \delta_{\mathrm{H}} 4.53\right]$ were supposed to be located. The structures of the modified ring $\mathrm{E}$ and side chain portions were determined by the following 2D NMR analysis. A three-proton doublet signal at $\delta 1.07(J=6.8 \mathrm{~Hz})$ was unambiguously assignable to Me-27. In the ${ }^{1} \mathrm{H}-{ }^{1} \mathrm{H}$ shift correlation spectroscopy (COSY) spectrum of $1, \mathrm{Me}-27$ was correlated to the broad multiplet signal of $\mathrm{H}-25$ centered at $\delta 2.10$, which exhibited correlations with a pair of oxymethylene protons at $\delta 4.16$ and $3.53\left(\mathrm{H}_{2}-26\right)$, and with a pair of methylene protons at $\delta 2.52$ and $2.16\left(\mathrm{H}_{2}-24\right)$. The methylene protons showed correlations with the olefinic proton of $\mathrm{H}-23$ at $\delta 4.53$. The $\mathrm{H}-23$ and $\mathrm{H}_{2}-24$ protons were associated with the olefinic carbon at $\delta 91.4$ and methylene carbon at $\delta 29.6$, respectively, by the ${ }^{1} \mathrm{H}$-detected heteronuclear multiple quantum coherence (HMQC) spectrum. In the ${ }^{1} \mathrm{H}$-detected heteronuclear multiple-bond connectivities (HMBC) spectrum, the $\mathrm{H}-23$ proton showed long-range correlations with the oxygenated $s p^{2}$ carbon at $\delta 163.7(\mathrm{C}-22)$ and $\mathrm{C}-24$ methylene carbon at $\delta 29.6$. Long-range correlations between C-22 and $\mathrm{H}-16(\delta 5.22) / \mathrm{H}_{2}-24$ were also noted. Thus, a linkage between $\mathrm{C}-16$ and $\mathrm{C}-22$ via an oxygen atom and the presence of the C-22(23) olefinic group were revealed. On the other hand, a deshielded singlet methyl signal at $\delta 1.73$ was assignable to Me-21 and exhibited a ${ }^{2} J_{\mathrm{C}, \mathrm{H}}$ correlation with a quaternary carbon bearing an oxygen atom at $\delta 76.7$ (C-20) and a ${ }^{3} J_{\mathrm{C}, \mathrm{H}}$ correlation with C-22. Further HMBC correlations were observed between $\mathrm{C}-20$ and $\mathrm{H}-16 / \mathrm{H}-17$ ( $\delta$ 2.25) (Fig. 1). These correlations were consistent with the presence of a hydroxy group at C-20. The geometry of the C-22(23) olefinic group was determined to be $Z$ based on an NOE correlation between Me-21 and H-23 in the phase-sensitive NOE correlation spectroscopy (NOESY) spectrum of $\mathbf{1}$.

When 1 was treated with $\beta$-D-glucosidase, it was hydrolyzed to gave a spirostanol glycoside (1a), identified as spirost-5-ene-3 $\beta, 20$-diol. ${ }^{9)}$ In the phase-sensitive NOESY spectrum of 1a, NOE correlations between H-12eq $(\delta 2.01)$ and Me-21 $(\delta 1.73), \mathrm{H}-14(\delta 0.92)$ and H-17 $(\delta 2.45), \mathrm{H}-16$ $(\delta$ 5.07) and H-17/H-23eq $(\delta$ 2.37), and between Me-18 $(\delta$ $1.20)$ and $\mathrm{Me}-21$, were indicative of the $\mathrm{D} / \mathrm{E}$ cis ring junction and the $20 S$ and $22 S$ configurations (Fig. 2). The configura-

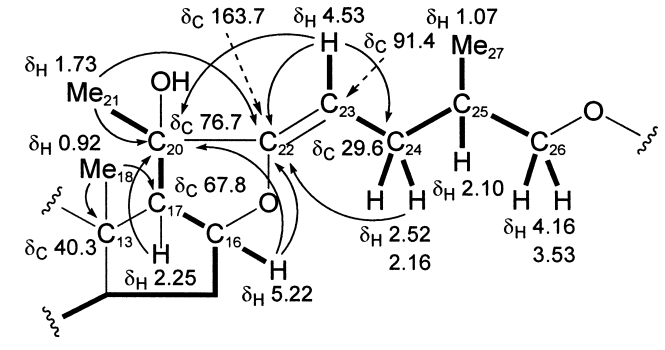

Fig. 1. ${ }^{1} \mathrm{H}$ Spin-Coupling Correlations (Bold Lines) and HMBC Correlations (Arrows) of the Rings D and E Parts, and Side-Chain Moiety of 1

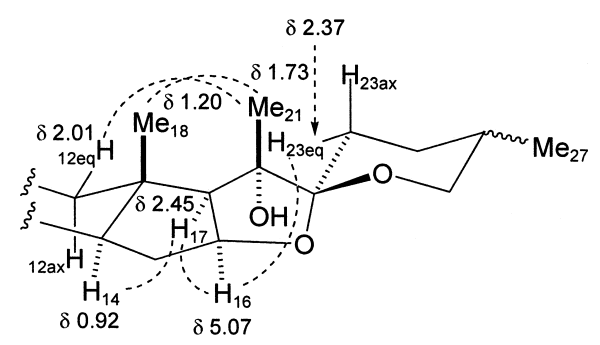

Fig. 2. NOE Correlations (Broken Lines) of the Rings D-F Parts of 1a

tion of $\mathrm{C}-25$ remains to be determined. Thus, the structure of 1 a was established as $(20 S, 22 S, 25 \xi)$-spirost-5-ene-3 $\beta, 20$ diol, and consequently the structure of the aglycone moiety of 1 was established as $(20 S, 22 Z, 25 \xi)$-furosta-5,22-diene3 $\beta, 20,26$-triol.

Finally, we focused our attention on determining the structures of the glycoside moieties. The ${ }^{1} \mathrm{H}-{ }^{1} \mathrm{H}$ COSY experiment allowed the sequential assignments from $\mathrm{H}-1$ to $\mathrm{H}_{2}-6$ and Me- 6 of five monosaccharides. Their signal multiplet patterns and coupling constants identified three $\beta$-D-glucopyranosyl $\left({ }^{4} \mathrm{C}_{1}\right)$ units and two $\alpha$-L-rhamnopyranosyl $\left({ }^{1} \mathrm{C}_{4}\right)$ units. The HMQC spectrum was applied to associate the protons with the corresponding one-bond coupled carbon resonances. Comparison of the carbon chemical shifts thus assigned with those of the reference methyl glycosides, ${ }^{10,11)}$ taking into account the known effects of $O$-glycosylation, indicated that $\mathbf{1}$ contained two terminal $\beta$-D-glucopyranosyl units (Glc'"' and Glc'"'"'), a C-2 and C-3 disubstituted $\beta$-D-glucopyranosyl unit (Glc'), a terminal $\alpha$-L-rhamnopyranosyl unit (Rha"), and a $\mathrm{C}$-4 substituted $\alpha$-L-rhamnopyranosyl unit (Rha'"). The $\beta$-orientations of the anomeric centers of the glucopyranosyl moieties were supported by the relatively large $J$ values of their anomeric protons $(J=7.6-7.8 \mathrm{~Hz})$. For the rhamnopyranosyl residues, the large ${ }^{1} J_{\mathrm{C}, \mathrm{H}}$ values $(170 \mathrm{~Hz}<)$ indicated that each anomeric proton was equatorial thus possessing an $\alpha$-pyranoid anomeric form. ${ }^{12)}$ In the HMBC spectrum of 1, longrange correlations were observed between $\delta 5.82$ (H-1 of $\left.\mathrm{Rha}^{\prime \prime}\right)$ and $\delta 78.6$ (C-2 of Glc'), $\delta 5.76$ (H-1 of Rha'"') and $\delta$ 86.2 (C-3 of Glc'), $\delta 5.25$ (H-1 of Glc'"'') and $\delta 84.5$ (C-4 of $\mathrm{Rha}^{\prime \prime \prime}$ ), $\delta 4.90$ (H-1 of $\mathrm{Glc}^{\prime}$ ) and $\delta 77.7$ (C-3 of aglycone), and between $\delta 4.85$ (H-1 of Glc'"'') and $\delta 75.3$ (C-26 of aglycone).

From the above spectroscopic and chemical data, the structure of 1 was formulated as $(20 S, 22 Z, 25 \xi)-26$ - [ $(\beta$-D-glucopyranosyl)oxy]-20-hydroxyfurosta-5,22-dien-3 $\beta$-yl $O-\beta$-Dglucopyranosyl-( $1 \rightarrow 4)$ - $\alpha$-L-rhamnopyranosyl- $(1 \rightarrow 3)-O$ - $[\alpha-$ L-rhamnopyranosyl- $(1 \rightarrow 2)]$ - $\beta$-D-glucopyranoside.

Compound 2 analyzed for $\mathrm{C}_{51} \mathrm{H}_{82} \mathrm{O}_{22}$ by combined HR- 
ESI-TOF-MS $\left(m / z \quad 1069.5106[\mathrm{M}+\mathrm{Na}]^{+}\right),{ }^{13} \mathrm{C}-\mathrm{NMR}$ and DEPT spectral data. The deduced molecular formula was less than that of $\mathbf{1}$ by a $\mathrm{C}_{6} \mathrm{H}_{10} \mathrm{O}_{5}$, corresponding to the lack of one hexose unit. The ${ }^{1} \mathrm{H}-\mathrm{NMR}$ spectrum of 2 showed signals for four anomeric protons at $\delta 5.88$ (br s), 5.76 (br s), 4.92 (d, $J=7.7 \mathrm{~Hz}$ ), and $4.85(\mathrm{~d}, J=7.8 \mathrm{~Hz})$, together with signals for four steroid methyl groups at $\delta 1.73(\mathrm{~s}), 1.08(\mathrm{~d}, J=6.8 \mathrm{~Hz})$, $1.07(\mathrm{~s})$, and $0.92(\mathrm{~s})$, and two olefinic protons at $\delta 5.32(\mathrm{brd}$, $J=4.8 \mathrm{~Hz})$ and $4.54(\mathrm{t}, J=7.3 \mathrm{~Hz})$. Acid hydrolysis of 2 with $1.0 \mathrm{M} \mathrm{HCl}$ in dioxane- $\mathrm{H}_{2} \mathrm{O}(1: 1)$ gave D-glucose and L-rhamnose. When the ${ }^{13} \mathrm{C}$-NMR spectrum of $\mathbf{2}$ was compared with those of $\mathbf{1}$, the signals assignable to one terminal $\beta$-D-glucopyranosyl group could not be detected, and the resonance for C-4 of the $\alpha$-L-rhamnopyranosyl group attached to C-3 of the inner $\beta$-D-glucopyranosyl moiety was shifted upfield by $10.9 \mathrm{ppm}$ and was observed at $\delta 73.6$ in 2 . All other signals appeared at almost the same positions between the two compounds. Analysis of the ${ }^{1} \mathrm{H}-{ }^{1} \mathrm{H}$ COSY and HMQC spectra of 2 revealed that 2 was composed of a C-2 and C-3 disubstituted $\beta$-D-glucopyranosyl unit $\left(\mathrm{Glc}^{\prime}\right)$, a terminal $\beta$-D-glucopyranosyl unit $\left(\mathrm{Glc}^{\prime \prime \prime \prime}\right)$, and two terminal $\alpha$-L-rhamnopyranosyl units (Rha" and Rha"'). In the HMBC spectrum of 2, long-range correlations were observed between $\delta 5.88(\mathrm{H}-1$ of Rha") and $\delta 78.3$ (C-2 of Glc'), $\delta 5.76$ (H-1 of Rha'") and $\delta 87.4$ (C-3 of Glc'), $\delta 4.92(\mathrm{H}-1$ of Glc' $)$ and $\delta 77.8$ (C-3 of aglycone), and between $\delta 4.85$ (H-1 of Glc'"') and $\delta 75.3(\mathrm{C}$ 26 of aglycone). Thus, the structure of 2 was $(20 S, 22 Z, 25 \xi)-$ 26 -[( $\beta$-D-glucopyranosyl)oxy]-20-hydroxyfurosta-5,22-dien$3 \beta$-yl $O$ - $\alpha$-L-rhamnopyranosyl- $(1 \rightarrow 2)-O$-[ $\alpha$-L-rhamnopyranosyl- $(1 \rightarrow 3)]$ - $\beta$-D-glucopyranoside.

Compound $3\left(\mathrm{C}_{70} \mathrm{H}_{116} \mathrm{O}_{38}\right)$ was obtained as an amorphous solid. The ${ }^{1} \mathrm{H}-\mathrm{NMR}$ spectrum of $\mathbf{3}$ showed two three-proton singlet signals at $\delta 0.97$ and 0.64 , indicating the presence of two angler methyl groups, three three-proton doublet signals at $\delta 0.95(J=6.2 \mathrm{~Hz}), 0.94(J=6.5 \mathrm{~Hz})$ and $0.78(J=6.6 \mathrm{~Hz})$ assignable to secondary methyl groups, and an olefinic proton signal at $\delta 5.30(\mathrm{~d}, J=4.5 \mathrm{~Hz})$, as well as signals for seven anomeric protons at $\delta 5.23(\mathrm{~d}, J=7.8 \mathrm{~Hz}), 5.22(\mathrm{~d}, J=$ $7.8 \mathrm{~Hz}$ ), 5.20 (d, $J=7.8 \mathrm{~Hz}), 5.19$ (d, $J=7.8 \mathrm{~Hz}), 5.07$ (d, $J=$ $7.7 \mathrm{~Hz}$ ), 5.04 (d, $J=7.7 \mathrm{~Hz}$ ) and 4.83 (d, $J=7.8 \mathrm{~Hz}$ ). Acid hydrolysis of 3 with $1.0 \mathrm{M} \mathrm{HCl}$ in dioxane- $\mathrm{H}_{2} \mathrm{O}(1: 1)$ gave an aglycone (3a), identified as $(24 R, 25 S)$-ergost-5-ene-3 $\beta, 26$ diol, ${ }^{7)}$ and D-glucose as the carbohydrate moiety. These data and the carbon chemical shifts of C-3 $(\delta 79.2)$ and C-26 $(\delta$ 73.9) suggested that $\mathbf{3}$ was a bisdesmosidic ergostanol heptaglucoside.

The severe overlapping of the proton signals for the sugar moieties, which was composed of seven $\beta$-D-glucopyranosyl units, excluded the possibility of a complete assignment in a straightforward way using a conventional heteronuclear COSY spectrum in 3. An ${ }^{1} \mathrm{H}$-detected heteronuclear single quantum coherence (HSQC)-totally correlated spectroscopy (TOCSY) technique was applied to solve the sugar sequence of 3, which correlates the anomeric protons with their respective skeleton carbons. ${ }^{13)}$ This allowed the identification of the ${ }^{13} \mathrm{C}$-NMR signals for all the monosaccharides and the substituted positions of the inner glycosyl moieties, with only little knowledge of the sequential ${ }^{1} \mathrm{H}-\mathrm{NMR}$ assignment. The HSQC-TOCSY spectrum showed that the anomeric proton signal at $\delta 4.83\left(\mathrm{~d}, J=7.8 \mathrm{~Hz}, \mathrm{H}-1^{\prime \prime \prime \prime}\right)$ was correlated to the $\delta$ 102.8 signal $\left(\mathrm{C}-1^{\prime \prime \prime \prime}\right)$ and then established that the next five carbon resonances for this sugar were $\delta 84.4\left(\mathrm{C}-2^{\prime \prime \prime \prime}\right), 77.8$

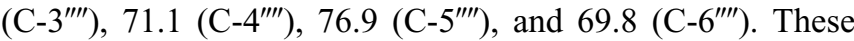
shift values gave an excellent match with literature data for $\beta$-D-glucopyranose glycosylated at $\mathrm{C}-2$ and $\mathrm{C}-6 .{ }^{14)} \mathrm{On}$ the $\mathrm{H}$ 1 tracks through the anomeric ${ }^{1} \mathrm{H} /{ }^{13} \mathrm{C}$ correlations at $\delta_{\mathrm{H} / \mathrm{C}}$ $5.04\left(\mathrm{H}-1^{\prime}\right) / 101.2\left(\mathrm{C}-1^{\prime}\right)$, five relayed cross-peaks extending to $\mathrm{C}-6$ were observed, with the carbon chemical shifts of $\delta$ $85.1\left(\mathrm{C}-2^{\prime}\right), 77.8\left(\mathrm{C}-3^{\prime}\right), 71.3\left(\mathrm{C}-4^{\prime}\right), 78.2\left(\mathrm{C}-5^{\prime}\right)$, and 62.6 $\left(\mathrm{C}-6^{\prime}\right)$, confirming the presence of a $\mathrm{C}-2$ substituted $\beta$-D-glucopyranosyl unit in 3 . The anomeric proton signals at $\delta 5.22$ $\left(\mathrm{H}-1^{\prime \prime}\right)$ and $5.23\left(\mathrm{H}-1^{\prime \prime \prime \prime \prime}\right)$ showed relayed correlation peaks with the respective six carbon signals in sequence at $\delta 106.3$ $\left(\mathrm{C}-1^{\prime \prime}\right), 76.2\left(\mathrm{C}-2^{\prime \prime}\right), 76.4\left(\mathrm{C}-3^{\prime \prime}\right), 81.3\left(\mathrm{C}-4^{\prime \prime}\right), 76.7\left(\mathrm{C}-5^{\prime \prime}\right)$, and $62.0\left(\mathrm{C}-6^{\prime \prime}\right)$; and $\delta 106.1\left(\mathrm{C}-1^{\prime \prime \prime \prime \prime}\right), 76.2\left(\mathrm{C}-2^{\prime \prime \prime \prime \prime \prime}\right), 76.3\left(\mathrm{C}-3^{\prime \prime \prime \prime \prime}\right)$, $81.2\left(\mathrm{C}-4^{\prime \prime \prime \prime \prime}\right), 76.8$ (C-5'"'"'), and $62.0\left(\mathrm{C}-6^{\prime \prime \prime \prime \prime}\right)$, indicative of two $\beta$-D-glucopyranosyl groups glycosylated at $\mathrm{C}-4$. The anomeric proton signals at $\delta 5.20\left(\mathrm{H}-1^{\prime \prime \prime}\right), 5.19\left(\mathrm{H}-1^{\prime \prime \prime \prime \prime \prime}\right)$, and $5.07\left(\mathrm{H}-1^{\prime \prime \prime \prime \prime \prime \prime \prime}\right)$ were correlated to the six carbon signals at $\delta$ 105.0 (C-1"' $), 74.8$ (C-2'"'), 78.2 (C-3'"'), 71.4 (C-4'"'), 78.4 (C$\left.5^{\prime \prime \prime}\right)$, and $62.4\left(\mathrm{C}-6^{\prime \prime \prime}\right) ; \delta 105.0\left(\mathrm{C}-1^{\prime \prime \prime \prime \prime \prime \prime}\right), 74.7\left(\mathrm{C}-2^{\prime \prime \prime \prime \prime \prime \prime}\right), 78.2$

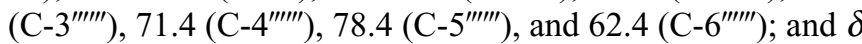

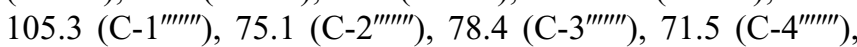
$78.4\left(\mathrm{C}-5^{\prime \prime \prime \prime \prime \prime \prime}\right)$, and $62.5\left(\mathrm{C}-6^{\prime \prime \prime \prime \prime \prime \prime \prime}\right)$, respectively, which corresponded to three terminal $\beta$-D-glucopyranosyl moieties. The above spectral information provided evidence for three termi-

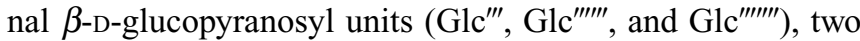
C-4 substituted $\beta$-D-glucopyranosyl units (Glc' and Glc $\left.{ }^{\prime \prime \prime \prime \prime}\right)$, a $\mathrm{C}$-2 substituted $\beta$-D-glucopyranosyl unit $\left(\mathrm{Glc}^{\prime}\right)$, and a C-2 and C-6 disubstituted $\beta$-D-glucopyranosyl unit (Glc'"') present in 3. In the HMBC spectrum of $\mathbf{3}$, correlation peaks were observed between $\delta 5.20$ (H-1 of Glc'") and $\delta 81.3$ (C-4 of $\left.\mathrm{Glc}^{\prime \prime}\right), \delta 5.22$ (H-1 of Glc $\left.{ }^{\prime \prime}\right)$ and $\delta 85.1$ (C-2 of Glc'), $\delta 5.04$ (H-1 of Glc') and $\delta 79.2$ (C-3 of aglycone), $\delta 5.19$ (H-1 of $\left.\mathrm{Glc}^{\prime \prime \prime \prime \prime \prime}\right)$ and $\delta 81.2$ (C-4 of Glc $\left.{ }^{\prime \prime \prime \prime \prime}\right), \delta 5.23$ (H-1 of Glc $\left.{ }^{\prime \prime \prime \prime \prime}\right)$ and

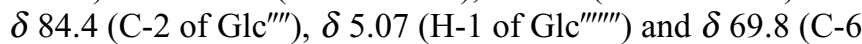
of Glc $\left.{ }^{\prime \prime \prime \prime}\right)$, and between $\delta 4.83\left(\mathrm{H}-1\right.$ of Glc $\left.{ }^{\prime \prime \prime \prime}\right)$ and $\delta 73.9(\mathrm{C}-$ 26 of aglycone). All of these data for 3 were consistent with the structure $(24 R, 25 S)-26-[(O-\beta$-D-glucopyranosyl- $(1 \rightarrow 4)$ $O$ - $\beta$-D-glucopyranosyl- $(1 \rightarrow 2)-O$ - $[\beta$-D-glucopyranosyl$(1 \rightarrow 6)]-\beta$-D-glucopyranosyl)oxy]ergost-5-en-3 $\beta$-yl $O$ - $\beta$-Dglucopyranosyl-( $1 \rightarrow 4)$ - $O$ - $\beta$-D-glucopyranosyl- $(1 \rightarrow 2)-\beta$-Dglucopyranoside.

Compound $4\left(\mathrm{C}_{52} \mathrm{H}_{84} \mathrm{O}_{23}\right)$ was obtained as an amorphous solid. The ${ }^{1} \mathrm{H}-\mathrm{NMR}$ spectrum of $\mathbf{4}$ showed signals for three secondary methyl groups at $\delta 1.36(\mathrm{~d}, J=5.7 \mathrm{~Hz}), 1.00(\mathrm{~d}$, $J=6.6 \mathrm{~Hz}$ ), and $0.96(\mathrm{~d}, J=6.6 \mathrm{~Hz})$, two angular methyl groups at $\delta 0.99$ and 0.58 (each s), and an olefinic proton at $\delta 5.32$ (br d, $J=4.4 \mathrm{~Hz}$ ), as observed for 3 , along with signals for four anomeric protons at $\delta 5.21(\mathrm{~d}, J=7.9 \mathrm{~Hz}), 5.19(\mathrm{~d}$, $J=7.8 \mathrm{~Hz}), 5.12(\mathrm{~d}, J=7.8 \mathrm{~Hz})$, and 5.00 (d, $J=7.9 \mathrm{~Hz})$. Acid hydrolysis of $\mathbf{4}$ gave D-glucose. The above spectral data and the result of acid hydrolysis suggested that $\mathbf{4}$ was an ergostanol derivative structurally related to $\mathbf{3}$. However, the molecular formula for the aglycone moiety was consistently calculated for $\mathrm{C}_{28} \mathrm{H}_{44} \mathrm{O}_{3}$, corresponding to seven degrees of unsaturation. Furthermore, an ester carbonyl group was shown to be present in the molecule of 4 by the IR $\left(1724 \mathrm{~cm}^{-1}\right)$ and ${ }^{13} \mathrm{C}-\mathrm{NMR}(\delta$ 174.2) spectra. These facts implied that the side-chain moiety was modified to form a lactone group. In the ${ }^{1} \mathrm{H}-{ }^{1} \mathrm{H}$ COSY spectrum of 4 , a broad methine proton signal centered at $\delta 1.91$ was shown to be 
coupled with the Me-21 doublet at $\delta 0.96$ and was assigned to H-20, which was then correlated to a methine proton at $\delta$ $1.04(\mathrm{H}-17)$ and an oxymethine proton at $\delta 4.38$ (H-22). Proton spin-coupling correlations could be successively traced out by the ${ }^{1} \mathrm{H}-{ }^{1} \mathrm{H}$ COSY spectrum, with the $\mathrm{H}-22$ signal as the starting point for analysis, resulting in the assignments of $\mathrm{H}_{2}-23(\delta 1.67,1.33), \mathrm{H}-24(\delta 1.59), \mathrm{H}-25$ ( $\left.\delta 2.05\right), \mathrm{Me}-27$ ( $\delta$ $1.36)$, and Me-28 $(\delta 1.00)$. Long-range correlations from $\mathrm{H}-$ $24, \mathrm{H}-25$, and Me-27 to the ester carbonyl carbon at $\delta 174.2$ allowed a carbonyl group at C-26 to be located. A six-membered lactone group formed between C-22 and C-26 was revealed by an HMBC correlation between the H-22 oxymethine proton and the $\mathrm{C}-26$ carbonyl carbon. The large $J$ value between $\mathrm{H}-17$ and $\mathrm{H}-20(\mathrm{~J}=11.1 \mathrm{~Hz})$ indicated that the $\mathrm{H}_{17}-\mathrm{C}_{17}-\mathrm{C}_{20}-\mathrm{H}_{20}$ part was preferably trans-oriented, and NOE correlations between Me-18 and H-20, H-12eq and Me-21, and between H-16 $\alpha$ and H-22 made it possible to confirm the $20 S^{*}$ configuration. Further NOEs between H-17 to $\mathrm{H}-23 \mathrm{eq}, \mathrm{H}-22$ and $\mathrm{H}-24$, and between $\mathrm{H}-23 \mathrm{ax}$ to $\mathrm{H}-25$ were consistent with the $22 R^{*}, 24 R^{*}$, and $25 S^{*}$ configurations, and suggestive of the chair-form-like conformation of the six-membered lactone group (Fig. 3).
The ${ }^{1} \mathrm{H}$ - and ${ }^{13} \mathrm{C}-\mathrm{NMR}$ data for the sugar moiety of $\mathbf{4}$, which was made up of four $\beta$-D-glucopyranosyl units, suggested that the glucosyl sequence was the same as that of the tetraglycoside residue lined to C-26 in 3. Confirmative evidence for the sugar sequence and its linkage position to the aglycone was obtained by long-range correlations between $\delta$ $5.21(\mathrm{H}-1$ of Glc'") and $\delta 81.5$ (C-4 of Glc'), $\delta 5.19$ (H-1 of $\left.\mathrm{Glc}^{\prime \prime}\right)$ and $\delta 85.1\left(\mathrm{C}-2\right.$ of $\left.\mathrm{Glc}^{\prime}\right), \delta 5.12\left(\mathrm{H}-1\right.$ of $\left.\mathrm{Glc}^{\prime \prime \prime \prime}\right)$ and $\delta$ 69.8 (C-6 of Glc'), and between $\delta 5.00(\mathrm{H}-1$ of Glc') and $\delta$ 79.7 (C-3 of aglycone). Thus, the structure of 4 was deter-

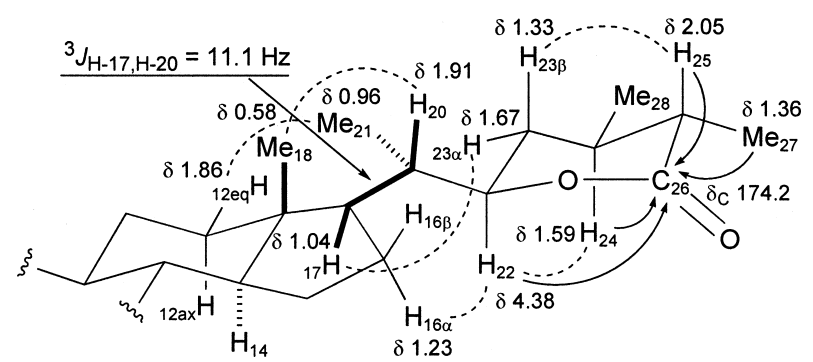

Fig. 3. NOE Correlations (Broken Lines) and HMBC Correlations (Arrows) of the Rings $\mathrm{C}-\mathrm{E}$ Parts of 4

Table 1. ${ }^{1} \mathrm{H}$ - and ${ }^{13} \mathrm{C}-\mathrm{NMR}$ Chemical Shift Assignments of the Aglycone Moiety of Compounds $\mathbf{1}$ and $\mathbf{4}$ in $\mathrm{C}_{5} \mathrm{D}_{5} \mathrm{~N}$

\begin{tabular}{|c|c|c|c|c|c|}
\hline \multicolumn{3}{|c|}{1} & \multicolumn{3}{|c|}{4} \\
\hline Position & ${ }^{1} \mathrm{H}$ & ${ }^{13} \mathrm{C}$ & Position & ${ }^{1} \mathrm{H}$ & ${ }^{13} \mathrm{C}$ \\
\hline $1 \mathrm{eq}$ & 1.74 & 37.5 & $1 \mathrm{eq}$ & 1.78 & 37.4 \\
\hline ax & 0.96 & & ax & 1.01 & \\
\hline $2 \mathrm{eq}$ & 2.09 & 30.1 & $2 \mathrm{eq}$ & 2.32 & 30.4 \\
\hline ax & 1.85 & & ax & 1.85 & \\
\hline 3 & $3.91 \mathrm{~m}$ & 77.7 & 3 & $3.83 \mathrm{~m}$ & 79.7 \\
\hline 4 eq & $2.75 \mathrm{dd}(11.7,3.8)^{a)}$ & 38.6 & 4 eq & $2.77 \mathrm{dd}(11.7,4.9)$ & 39.4 \\
\hline ax & $2.68 \mathrm{dd}(11.7,11.7)$ & & ax & $2.64 \mathrm{dd}(11.7,11.7)$ & \\
\hline 5 & - & 140.8 & 5 & - & 141.1 \\
\hline 6 & 5.32 br d (4.4) & 121.8 & 6 & 5.32 br d (4.4) & 121.6 \\
\hline 7 eq & 1.86 & 32.0 & 7 eq & 1.85 & 32.1 \\
\hline ax & 1.48 & & ax & 1.48 & \\
\hline 8 & 1.54 & 31.1 & 8 & 1.32 & 32.0 \\
\hline 9 & 0.86 & 50.1 & 9 & 0.86 & 50.2 \\
\hline 10 & - & 37.0 & 10 & - & 36.8 \\
\hline $11(2 \mathrm{H})$ & 1.42 & 20.5 & $11 \mathrm{eq}$ & 1.40 & 21.2 \\
\hline & & & $\mathrm{ax}$ & 1.31 & \\
\hline $12 \mathrm{eq}$ & 1.90 & 39.3 & $12 \mathrm{eq}$ & 1.86 & 39.8 \\
\hline $\mathrm{ax}$ & 1.18 & & ax & 1.04 & \\
\hline 13 & - & 40.3 & 13 & - & 42.8 \\
\hline 14 & 0.96 & 56.9 & 14 & 0.86 & 56.3 \\
\hline 15 & 2.08 & 33.5 & 15 & 1.51 & 24.5 \\
\hline & 1.52 & & & 1.01 & \\
\hline 16 & 5.22 & 84.2 & 16 & 1.23 & 27.3 \\
\hline & & & & 1.59 & \\
\hline 17 & $2.25 \mathrm{~d}(6.3)$ & 67.8 & 17 & 1.04 br dd $(11.1,8.8)$ & 52.1 \\
\hline 18 & $0.92 \mathrm{~s}$ & 13.5 & 18 & $0.58 \mathrm{~s}$ & 11.7 \\
\hline 19 & $1.06 \mathrm{~s}$ & 19.4 & 19 & $0.99 \mathrm{~s}$ & 19.5 \\
\hline 20 & - & 76.7 & 20 & 1.91 & 39.9 \\
\hline 21 & $1.73 \mathrm{~s}$ & 21.9 & 21 & $0.96 \mathrm{~d}(6.6)$ & 13.0 \\
\hline 22 & - & 163.7 & 22 & 4.38 & 82.0 \\
\hline 23 & $4.53 \mathrm{t}(6.9)$ & 91.4 & 23 & 1.67 ddd $(13.6,3.1,2.7)$ & 30.8 \\
\hline & & & & 1.33 ddd $(13.6,12.1,12.1)$ & \\
\hline $24 \mathrm{a}$ & 2.52 & 29.6 & 24 & 1.59 & 34.1 \\
\hline $\mathrm{b}$ & 2.16 & & & & \\
\hline 25 & 2.10 & 34.8 & 25 & $2.05 \mathrm{dq}(10.9,5.7)$ & 43.8 \\
\hline $26 \mathrm{a}$ & $4.16 \mathrm{dd}(9.3,5.7)$ & 75.3 & 26 & - & 174.2 \\
\hline $\mathrm{b}$ & $3.53 \mathrm{dd}(9.3,7.2)$ & & 27 & $1.36 \mathrm{~d}(5.7)$ & 15.1 \\
\hline 27 & $1.07 \mathrm{~d}(6.8)$ & 17.4 & 28 & $1.00 \mathrm{~d}(6.6)$ & 20.4 \\
\hline
\end{tabular}

a) The values in parentheses are coupling constants in $\mathrm{Hz}$. 
Table 2. ${ }^{1} \mathrm{H}$ - and ${ }^{13} \mathrm{C}-\mathrm{NMR}$ Chemical Shift Assignments for the Sugar Moieties of Compounds $\mathbf{1}$ and $\mathbf{2}$ in $\mathrm{C}_{5} \mathrm{D}_{5} \mathrm{~N}$

\begin{tabular}{|c|c|c|c|c|c|}
\hline \multicolumn{3}{|c|}{1} & \multicolumn{3}{|c|}{2} \\
\hline Position & ${ }^{1} \mathrm{H}$ & ${ }^{13} \mathrm{C}$ & Position & ${ }^{1} \mathrm{H}$ & ${ }^{13} \mathrm{C}$ \\
\hline $1^{\prime}$ & $4.90 \mathrm{~d}(7.6)^{a)}$ & 99.8 & $1^{\prime}$ & $4.92 \mathrm{~d}(7.7)$ & 99.9 \\
\hline $2^{\prime}$ & $4.06 \mathrm{dd}(9.0,7.6)$ & 78.6 & $2^{\prime}$ & $4.08 \mathrm{dd}(8.9,7.7)$ & 78.3 \\
\hline $3^{\prime}$ & $4.18 \mathrm{dd}(9.0,9.0)$ & 86.2 & $3^{\prime}$ & $4.18 \mathrm{dd}(8.9,8.9)$ & 87.4 \\
\hline $4^{\prime}$ & $4.09 \mathrm{~m}$ & 69.7 & $4^{\prime}$ & 4.07 & 69.9 \\
\hline $5^{\prime}$ & $3.79 \mathrm{~m}$ & 78.0 & $5^{\prime}$ & $3.81 \mathrm{~m}$ & 78.1 \\
\hline $\begin{array}{lll}6^{\prime} & \mathrm{a}\end{array}$ & $4.44 \mathrm{~m}$ & 62.2 & $\begin{array}{lll}6^{\prime} & \mathrm{a}\end{array}$ & 4.45 brd (10.9) & 62.3 \\
\hline $\mathrm{b}$ & $4.37 \mathrm{~m}$ & & $\mathrm{~b}$ & 4.34 & \\
\hline $1^{\prime \prime}$ & $5.82 \mathrm{brs}$ & 102.6 & $1^{\prime \prime}$ & $5.88 \mathrm{brs}$ & 102.6 \\
\hline $2^{\prime \prime}$ & 4.74 br d $(2.0)$ & 72.5 & $2^{\prime \prime}$ & $4.75 \mathrm{brd}(3.2)$ & 72.5 \\
\hline $3^{\prime \prime}$ & $4.53 \mathrm{dd}(9.5,2.0)$ & 72.8 & $3^{\prime \prime}$ & $4.53 \mathrm{dd}(9.3,3.2)$ & 72.8 \\
\hline $4^{\prime \prime}$ & $4.32 \mathrm{dd}(9.5,9.5)$ & 73.8 & $4^{\prime \prime}$ & $4.32 \mathrm{dd}(9.3,9.3)$ & 73.8 \\
\hline $5^{\prime \prime}$ & $4.88 \mathrm{dq}(9.5,6.2)$ & 69.9 & $5^{\prime \prime}$ & $4.88 \mathrm{dq}(9.3,6.2)$ & 69.6 \\
\hline $6^{\prime \prime}$ & $1.76 \mathrm{~d}(6.2)$ & 18.7 & $6^{\prime \prime}$ & $1.76 \mathrm{~d}(6.2)$ & 18.7 \\
\hline $1^{\prime \prime \prime}$ & 5.76 brs & 103.1 & $1^{\prime \prime \prime}$ & 5.76 brs & 103.9 \\
\hline $2^{\prime \prime \prime}$ & $4.81 \mathrm{brd}(2.8)$ & 72.0 & $2^{\prime \prime \prime}$ & $4.86 \mathrm{brd}(3.2)$ & 72.6 \\
\hline $3^{\prime \prime \prime}$ & $4.58 \mathrm{dd}(9.3,2.8)$ & 72.4 & $3^{\prime \prime \prime}$ & $4.49 \mathrm{dd}(9.3,3.2)$ & 72.5 \\
\hline $4^{\prime \prime \prime}$ & $4.44 \mathrm{dd}(9.3,9.3)$ & 84.5 & $4^{\prime \prime \prime}$ & $4.32 \mathrm{dd}(9.3,9.3)$ & 73.6 \\
\hline $5^{\prime \prime \prime}$ & $4.84 \mathrm{dq}(9.3,6.2)$ & 68.7 & $5^{\prime \prime \prime}$ & $4.78 \mathrm{dq}(9.3,6.1)$ & 70.6 \\
\hline $6^{\prime \prime \prime}$ & $1.69 \mathrm{~d}(6.2)$ & 18.3 & $6^{\prime \prime \prime}$ & $1.66 \mathrm{~d}(6.1)$ & 18.4 \\
\hline $1^{\prime \prime \prime \prime}$ & $5.25 \mathrm{~d}(7.8)$ & 106.5 & $1^{\prime \prime \prime \prime}$ & $4.85 \mathrm{~d}(7.8)$ & 105.1 \\
\hline $2^{\prime \prime \prime \prime}$ & $4.11 \mathrm{dd}(9.0,7.8)$ & 76.4 & $2^{\prime \prime \prime \prime}$ & $4.05 \mathrm{dd}(8.5,7.8)$ & 75.3 \\
\hline $3^{\prime \prime \prime \prime}$ & $4.21 \mathrm{dd}(9.0,9.0)$ & 78.6 & $3^{\prime \prime \prime \prime}$ & $4.24 \mathrm{~m}$ & 78.6 \\
\hline $4^{\prime \prime \prime \prime \prime}$ & $4.29 \mathrm{dd}(9.0,9.0)$ & 71.4 & $4^{\prime \prime \prime \prime \prime}$ & $4.25 \mathrm{~m}$ & 71.7 \\
\hline $5^{\prime \prime \prime \prime}$ & $3.78 \mathrm{~m}$ & 78.4 & $5^{\prime \prime \prime \prime}$ & $3.94 \mathrm{~m}$ & 78.4 \\
\hline $6^{\prime \prime \prime \prime}$ a & $4.41 \mathrm{~m}$ & 62.5 & $6^{\prime \prime \prime \prime}$ a & $4.54 \mathrm{~m}$ & 62.8 \\
\hline $\mathrm{b}$ & $4.36 \mathrm{~m}$ & & $\mathrm{~b}$ & $4.40 \mathrm{dd}(11.6,4.9)$ & \\
\hline $1^{\prime \prime \prime \prime \prime}$ & $4.85 \mathrm{~d}(7.7)$ & 105.1 & & & \\
\hline $2^{\prime \prime \prime \prime \prime \prime}$ & $4.05 \mathrm{dd}(8.6,7.7)$ & 75.3 & & & \\
\hline $3^{\prime \prime \prime \prime \prime \prime}$ & $4.25 \mathrm{dd}(9.1,8.6)$ & 78.6 & & & \\
\hline $4^{\prime \prime \prime \prime \prime \prime}$ & $4.26 \mathrm{dd}(9.1,9.1)$ & 71.6 & & & \\
\hline $5^{\prime \prime \prime \prime \prime}$ & $3.94 \mathrm{~m}$ & 78.4 & & & \\
\hline $6^{\prime \prime \prime \prime \prime}$ a & $4.55 \mathrm{~m}$ & 62.7 & & & \\
\hline $\mathrm{b}$ & $4.39 \mathrm{~m}$ & & & & \\
\hline
\end{tabular}

a) The values in parentheses are coupling constants in $\mathrm{Hz}$.

mined to be $\left(22 R^{*}, 24 R^{*}, 25 S^{*}\right)-3 \beta-[(O-\beta$-D-glucopyranosyl$(1 \rightarrow 4)-O$ - $\beta$-D-glucopyranosyl-( $1 \rightarrow 2)-O$-[ $\beta$-D-glucopyranosyl-(1 $\rightarrow 6)]$ - $\beta$-D-glucopyranosyl)oxy]-22-hydroxyergost-5en-26-oic acid $\delta$-lactone.

Compound $\mathbf{5}$ was shown to have the molecular formula of $\mathrm{C}_{23} \mathrm{H}_{26} \mathrm{O}_{13}$ by the data of the HR-ESI-TOF-MS ( $\mathrm{m} / z 533.1244$ $\left.[\mathrm{M}+\mathrm{Na}]^{+}\right)$. The ${ }^{1} \mathrm{H}-\mathrm{NMR}$ spectrum of $\mathbf{5}$ showed signals for a 1,2,4-trisubstituted aromatic group at $\delta 7.57(\mathrm{~d}, J=1.8 \mathrm{~Hz})$, 7.36 (dd, $J=8.5,1.8 \mathrm{~Hz}$ ), and $7.09(\mathrm{~d}, J=8.5 \mathrm{~Hz}$ ), a symmetrically 1,3,4,5-tetrasubstituted aromatic group at $\delta 7.30(2 \mathrm{H}$, br s), and three methoxy groups at $\delta 3.87(3 \mathrm{H}, \mathrm{s})$ and 3.83 $(3 \mathrm{H} \times 2, \mathrm{~s})$, together with an anomeric proton at $\delta 5.05(\mathrm{~d}$, $J=7.4 \mathrm{~Hz}$ ). In the ${ }^{13} \mathrm{C}$-NMR spectrum, five oxygenated $s p^{2}$ carbons were observed at $\delta 151.6,150.4,149.0 \times 2$, and 142.3. Treatment of 5 with $6 \% \mathrm{NaOMe}$ in $\mathrm{MeOH}$ resulted in the production of a phenolic glucoside, identified as $4-(\beta$-Dglucopyranosyloxy)-3-methoxybenzoic acid $(\mathbf{5 a})^{15)}$ and methyl 4-hydroxy-3,5-dimethoxybenzoate. These data implied that $\mathbf{5}$ was a 4-hydroxy-3,5-dimethoxybenzoyl ester of 5a. The 4-hydroxy-3,5-dimethoxybenzoyl group was shown to be involved in an ester linkage at the glucose C-6 position in 5 by HMBC correlations of the $\mathrm{H}_{2}-6$ protons of the glucosyl residue at $\delta 4.72$ and 4.38 with the ester carbonyl carbon of the 4-hydroxy-3,5-dimethoxybenzoyl residue at $\delta 167.8$. Accordingly, the structure of the new phenolic glucoside 5 was elucidated as 4-[6-O-(4-hydroxy-3,5-dimethoxybenzoyl)-
$\beta$-D-glucopyranosyloxy]-3-methoxybenzoic acid.

The isolated compounds were evaluated for their cytotoxic activity against HL-60 human promyelocytic leukemia cells. None of the compounds was cytotoxic against HL-60 cells at a sample concentration of $10 \mu \mathrm{g} / \mathrm{ml}$.

\section{Experimental}

Optical rotations were measured using a JASCO DIP-360 (Tokyo, Japan) automatic digital polarimeter. IR spectra were recorded on a JASCO FT-IR 620 spectrophotometer, and UV spectrum on a JASCO V-520 spectrophotometer. NMR spectra were recorded on a Bruker DRX-500 $(500 \mathrm{MHz}$ for ${ }^{1}$ H-NMR, Karlsruhe, Germany) spectrophotometer using standard Bruker pulse programs. Chemical shifts were given as $\delta$ values with reference to tetramethylsilane (TMS) as an internal standard. ESI-TOF-MS data were obtained on a Micromass LCT (Manchester, U.K.) mass spectrometer. Elemental analysis was carried out using an Elementar Vario EL elemental analyzer (Hanau, Germany). Diaion HP-20 (Mitsubishi-Chemical, Tokyo, Japan), silica gel (Fuji-Silysia Chemical, Aichi, Japan), and ODS silica gel (Nacalai Tesque, Kyoto, Japan) were used for column chromatography. TLC was carried out on precoated Kieselgel $60 \mathrm{~F}_{254}(0.25 \mathrm{~mm}$ thick, Merck, Darmstadt, Germany) and $\mathrm{RP}_{18} \mathrm{~F}_{254} \mathrm{~S}$ plates $(0.25 \mathrm{~mm}$ thick, Merck), and spots were visualized by spraying the plates with $10 \% \mathrm{H}_{2} \mathrm{SO}_{4}$ solution, followed by heating. HPLC was performed by using a system composed of a CCPM pump (Tosoh, Tokyo, Japan), a CCP PX-8010 controller (Tosoh), an RI-8010 (Tosoh) or a Shodex OR-2 (Showa-Denko, Tokyo, Japan) detector, and a Rheodyne injection port. All chemicals used were of biochemical reagent grade.

Plant Material The rhizomes of T. chantrieri were collected in Si Mao City, Yunnan Province, People's Republic of China, in October 1996, and identified by Dr. Yutaka Sashida, emeritus professor of the Tokyo University of Pharmacy and Life Sciences. A voucher specimen has been deposited in 
our laboratory (voucher no. TC-96-003, Laboratory of Medicinal Pharmacognosy).

Extraction and Isolation The plant material (dry weight, $7.3 \mathrm{~kg}$ ) was extracted with hot $\mathrm{MeOH}$ twice (101 each time). The $\mathrm{MeOH}$ extract was concentrated under reduced pressure, and the extract was passed through a Diaion HP-20 column eluted with $30 \% \mathrm{MeOH}, \mathrm{MeOH}$, and EtOAc. Column chromatography of the $\mathrm{MeOH}$ eluate portion on silica gel and elution with a stepwise gradient mixture of $\mathrm{CHCl}_{3}-\mathrm{MeOH}(9: 1 ; 4: 1 ; 3: 1 ; 2: 1 ; 1: 1)$, and finally with $\mathrm{MeOH}$ alone, gave five fractions $(\mathrm{I}-\mathrm{V})$. Fraction $\mathrm{V}$ was subjected to column chromatography on silica gel eluted with $\mathrm{CHCl}_{3}-\mathrm{MeOH}-$ $\mathrm{H}_{2} \mathrm{O}(60: 10: 1 ; 50: 10: 1 ; 40: 10: 1)$ and ODS silica gel with $\mathrm{MeOH}-\mathrm{H}_{2} \mathrm{O}$ $(8: 5)$ and $\mathrm{MeCN}-\mathrm{H}_{2} \mathrm{O}(1: 3 ; 2: 5)$ to give $\mathbf{1}(40 \mathrm{mg}), \mathbf{2}(8.0 \mathrm{mg}), \mathbf{3}(16 \mathrm{mg})$, $4(9.0 \mathrm{mg})$, and $5(7.0 \mathrm{mg})$.

Compound 1: Amorphous solid, $[\alpha]_{\mathrm{D}}^{25}-44.0^{\circ}\left(c=0.10 ; \mathrm{CHCl}_{3}-\mathrm{MeOH}\right.$, $1: 1)$. HR-ESI-TOF-MS $m / z: 1231.5692[\mathrm{M}+\mathrm{Na}]^{+}\left(\mathrm{Calcd}\right.$ for $\mathrm{C}_{57} \mathrm{H}_{92} \mathrm{O}_{27} \mathrm{Na}$, 1231.5724). IR (film) $v_{\max } \mathrm{cm}^{-1}: 3389(\mathrm{OH}), 2934(\mathrm{CH}), 1644,1043 .{ }^{1} \mathrm{H}-$ and ${ }^{13} \mathrm{C}$-NMR, see Tables 1 and 2.

Acid Hydrolysis of 1 A solution of $1(4.5 \mathrm{mg})$ in $1 \mathrm{M} \mathrm{HCl}$ (dioxane$\mathrm{H}_{2} \mathrm{O}, 1: 1,2 \mathrm{ml}$ ) was heated at $95^{\circ} \mathrm{C}$ for $1 \mathrm{~h}$ under an $\mathrm{Ar}$ atmosphere. After cooling, the reaction mixture was neutralized by passage through an Amberlite IRA-93ZU (Organo, Tokyo, Japan) column and chromatographed on silica gel eluted with $\mathrm{CHCl}_{3}-\mathrm{MeOH}-\mathrm{H}_{2} \mathrm{O}(40: 10: 1)$ to give a sugar fraction $(1.5 \mathrm{mg})$. The sugar fraction was dissolved in $\mathrm{H}_{2} \mathrm{O}(1 \mathrm{ml})$ and passed through a Sep-Pak $\mathrm{C}_{18}$ cartridge (Waters, Milford, MA, U.S.A.), which was then analyzed by HPLC under the following conditions: column, Capcell Pak NH2 UG80 ( $4.6 \mathrm{~mm}$ i.d. $\times 250 \mathrm{~mm}, 5 \mu \mathrm{m}$, Shiseido, Tokyo, Japan); solvent, $\mathrm{MeCN}-\mathrm{H}_{2} \mathrm{O}(17: 3)$; flow rate, $0.9 \mathrm{ml} / \mathrm{min}$; detection, $\mathrm{RI}$ and $\mathrm{OR}$. Identification of D-glucose and L-rhamnose present in the sugar fraction was carried out by comparison of their retention times and optical rotations with those of authentic samples. $t_{\mathrm{R}}(\mathrm{min}): 7.09$ (L-rhamnose, negative optical rotation), 13.01 (D-glucose, positive optical rotation).

Enzymatic Hydrolysis of 1 Compound $\mathbf{1}(34 \mathrm{mg})$ was dissolved in an HOAc/KOAc buffer (pH 4.3, $10 \mathrm{ml}$ ) with naringinase (Sigma, St. Louis, MO, U.S.A., EC 232-296-4) (49 mg) and incubated at room temperature for $10 \mathrm{~h}$. The crude mixture was chromatographed on silica gel eluted with $\mathrm{CHCl}_{3}-\mathrm{MeOH}-\mathrm{H}_{2} \mathrm{O}(40: 10: 1)$ to yield $\mathbf{1 a}(5.0 \mathrm{mg})$ and D-glucose $(3.0 \mathrm{mg})$.

Compound 1a: Amorphous solid, $[\alpha]_{\mathrm{D}}^{28}-18.0^{\circ}\left(c=0.10 ; \mathrm{CHCl}_{3}-\mathrm{MeOH}\right.$, $1: 1)$. HR-ESI-TOF-MS $m / z: 1069.5287[\mathrm{M}+\mathrm{Na}]^{+}\left(\mathrm{Calcd}\right.$ for $\mathrm{C}_{51} \mathrm{H}_{82} \mathrm{O}_{22} \mathrm{Na}$, 1069.5195). IR (film) $v_{\mathrm{max}} \mathrm{cm}^{-1}: 3388(\mathrm{OH}), 2929(\mathrm{CH}), 1454,1379,1260$ 1043. ${ }^{1} \mathrm{H}-\mathrm{NMR}\left(500 \mathrm{MHz}, \mathrm{C}_{5} \mathrm{D}_{5} \mathrm{~N}\right) \delta: 5.81\left(1 \mathrm{H}, \mathrm{br} \mathrm{s}, \mathrm{H}-1^{\prime \prime}\right), 5.75(1 \mathrm{H}, \mathrm{br} \mathrm{s}$, H-1"'), $5.34(1 \mathrm{H}, \mathrm{d}, J=4.3 \mathrm{~Hz}, \mathrm{H}-6), 5.24\left(1 \mathrm{H}, \mathrm{d}, J=7.8 \mathrm{~Hz}, \mathrm{H}-1^{\prime \prime \prime \prime}\right), 5.07$ $(1 \mathrm{H}, \mathrm{m}, \mathrm{H}-16), 4.90\left(1 \mathrm{H}, \mathrm{d}, J=7.6 \mathrm{~Hz}, \mathrm{H}-1^{\prime}\right), 3.91(1 \mathrm{H}, \mathrm{m}, \mathrm{H}-3), 3.68(1 \mathrm{H}$, dd, $J=10.5,10.5 \mathrm{~Hz}, \mathrm{H}-26 \mathrm{ax}), 3.59(1 \mathrm{H}, \mathrm{dd}, J=10.5,2.7 \mathrm{~Hz}, \mathrm{H}-26 \mathrm{eq}), 2.45$ $(1 \mathrm{H}, \mathrm{d}, J=8.4 \mathrm{~Hz}, \mathrm{H}-17), 2.37$ (1H, m, H-23eq), $2.01(1 \mathrm{H}, \mathrm{m}, \mathrm{H}-12 \mathrm{eq}), 1.81$ $(1 \mathrm{H}, \mathrm{m}, \mathrm{H}-23 \mathrm{ax}), 1.76\left(3 \mathrm{H}, \mathrm{d}, J=6.2 \mathrm{~Hz}, \mathrm{Me}-6^{\prime \prime}\right), 1.73(3 \mathrm{H}, \mathrm{s}, \mathrm{Me}-21), 1.69$ $\left(3 \mathrm{H}, \mathrm{d}, J=6.2 \mathrm{~Hz}, \mathrm{Me}-6^{\prime \prime \prime}\right), 1.65(1 \mathrm{H}, \mathrm{m}, \mathrm{H}-25), 1.23(1 \mathrm{H}, \mathrm{m}, \mathrm{H}-12 \mathrm{ax}), 1.20$ $(3 \mathrm{H}, \mathrm{s}, \mathrm{Me}-18), 1.10(3 \mathrm{H}, \mathrm{s}, \mathrm{Me}-19), 0.92(1 \mathrm{H}, \mathrm{m}, \mathrm{H}-14), 0.74(3 \mathrm{H}, \mathrm{d}$ $J=5.3 \mathrm{~Hz}, \mathrm{Me}-27) .{ }^{13} \mathrm{C}-\mathrm{NMR}\left(125 \mathrm{MHz}, \mathrm{C}_{5} \mathrm{D}_{5} \mathrm{~N}\right) \delta: 37.5,30.1,77.8,38.7$, $140.8,121.9,32.3,30.8,50.3,37.1,20.9,41.4,41.6,56.4,34.2,82.8,70.2$, $15.8,19.4,82.6,20.4,110.1,30.2,29.5,30.6,67.3,17.3$ (C-1-C-27), 99.8, 78.6, 86.3, 69.7, 78.0, $62.2\left(\mathrm{C}-1^{\prime}-\mathrm{C}-6^{\prime}\right), 102.6,72.5,72.8,73.8,69.9,18.7$ $\left(\mathrm{C}-1^{\prime \prime}-\mathrm{C}-6^{\prime \prime}\right), 103.2,72.1,72.4,84.4,68.7,18.3$ (C-1"'-C-6"'), 106.5, 76.4, 78.6, 71.4, 78.4, $62.6\left(\mathrm{C}-1^{\prime \prime \prime \prime}-\mathrm{C}-6^{\prime \prime \prime}\right)$

Compound 2: Amorphous solid, $[\alpha]_{\mathrm{D}}^{25}-46.0^{\circ}\left(c=0.10 ; \mathrm{CHCl}_{3}-\mathrm{MeOH}\right.$, $1: 1)$. HR-ESI-TOF-MS $m / z: 1069.5106[\mathrm{M}+\mathrm{Na}]^{+}\left(\right.$Calcd for $\mathrm{C}_{51} \mathrm{H}_{82} \mathrm{O}_{22} \mathrm{Na}$, 1069.5195). IR (film) $v_{\max } \mathrm{cm}^{-1}: 3389(\mathrm{OH}), 2929(\mathrm{CH}), 1651,1040 .{ }^{1} \mathrm{H}-$ NMR $\left(500 \mathrm{MHz}, \mathrm{C}_{5} \mathrm{D}_{5} \mathrm{~N}\right) \delta: 5.32(1 \mathrm{H}, \mathrm{d}, J=4.8 \mathrm{~Hz}, \mathrm{H}-6), 5.22(1 \mathrm{H}, \mathrm{m}, \mathrm{H}-$ 16), $4.54(1 \mathrm{H}, \mathrm{t}, J=7.3 \mathrm{~Hz}, \mathrm{H}-23), 4.16(1 \mathrm{H}, \mathrm{dd}, J=9.5,5.8 \mathrm{~Hz}, \mathrm{H}-26 \mathrm{a}), 3.92$ $(1 \mathrm{H}, \mathrm{m}, \mathrm{H}-3), 3.54(1 \mathrm{H}, \mathrm{dd}, J=9.5,7.1 \mathrm{~Hz}, \mathrm{H}-26 \mathrm{~b}), 2.25(1 \mathrm{H}, \mathrm{d}, J=6.3 \mathrm{~Hz}$, H-17), 1.73 (3H, s, Me-21), $1.08(3 \mathrm{H}, \mathrm{d}, J=6.8 \mathrm{~Hz}, \mathrm{Me}-27), 1.07(3 \mathrm{H}, \mathrm{s}$, Me-19), 0.92 (3H, s, Me-18). Signals for the sugar moieties, see Table 2. ${ }^{13} \mathrm{C}$-NMR $\left(125 \mathrm{MHz}, \mathrm{C}_{5} \mathrm{D}_{5} \mathrm{~N}\right) \delta: 37.5,30.1,77.8,38.7,140.8,121.8,32.0$, $31.1,50.1,37.0,20.6,39.3,40.4,57.0,33.5,84.2,67.8,13.5,19.4,76.7$, $21.9,163.7,91.4,29.6,34.8,75.3,17.4(\mathrm{C}-1-\mathrm{C}-27)$. Signals for the sugar moieties, see Table 2 .

Acid Hydrolysis of 2 A solution of $\mathbf{2}(6.0 \mathrm{mg})$ was subjected to acid hydrolysis as described for $\mathbf{1}$ to give a sugar fraction $(2.0 \mathrm{mg})$. HPLC analysis of the sugar fraction under the same conditions as in the case of $\mathbf{1}$ showed the presence of D-glucose and L-rhamnose. $t_{\mathrm{R}}(\mathrm{min})$ : 7.03 (L-rhamnose, negative optical rotation), 12.96 (D-glucose, positive optical rotation).

Compound 3: Amorphous solid, $[\alpha]_{\mathrm{D}}^{28}-26.0^{\circ}(c=0.10$, MeOH). ESITOF-MS $m / z: 1573[\mathrm{M}+\mathrm{Na}]^{+}$. Anal. Calcd for $\mathrm{C}_{70} \mathrm{H}_{116} \mathrm{O}_{38} \cdot 4 \mathrm{H}_{2} \mathrm{O}, \mathrm{C}, 51.34$ H, 7.63. Found: C, 51.63; H, 8.06. IR (film) $v_{\max } \mathrm{cm}^{-1}: 3375(\mathrm{OH}), 2932$
(CH), 1072, 1033. ${ }^{1} \mathrm{H}-\mathrm{NMR}\left(500 \mathrm{MHz}, \mathrm{C}_{5} \mathrm{D}_{5} \mathrm{~N}\right) \delta: 5.30(1 \mathrm{H}$, br d, $J=4.5 \mathrm{~Hz}$, H-6), $5.23\left(1 \mathrm{H}, \mathrm{d}, J=7.8 \mathrm{~Hz}, \mathrm{H}-1^{\prime \prime \prime \prime \prime}\right), 5.22\left(1 \mathrm{H}, \mathrm{d}, J=7.8 \mathrm{~Hz}, \mathrm{H}-1^{\prime \prime}\right), 5.20$ $\left(1 \mathrm{H}, \mathrm{d}, J=7.8 \mathrm{~Hz}, \mathrm{H}-1^{\prime \prime \prime}\right), 5.19\left(1 \mathrm{H}, \mathrm{d}, J=7.8 \mathrm{~Hz}, \mathrm{H}-1^{\prime \prime \prime \prime \prime \prime}\right), 5.07(1 \mathrm{H}, \mathrm{d}, J=7.7$ $\left.\mathrm{Hz}, \mathrm{H}-1^{\prime \prime \prime \prime \prime \prime \prime \prime}\right), 5.04\left(1 \mathrm{H}, \mathrm{d}, J=7.7 \mathrm{~Hz}, \mathrm{H}-1^{\prime}\right), 4.83\left(1 \mathrm{H}, \mathrm{d}, J=7.8 \mathrm{~Hz}, \mathrm{H}-1^{\prime \prime \prime \prime}\right)$, $4.13(1 \mathrm{H}, \mathrm{m}, \mathrm{H}-26 \mathrm{a}), 3.82(1 \mathrm{H}, \mathrm{m}, \mathrm{H}-3), 3.40(1 \mathrm{H}, \mathrm{m}, \mathrm{H}-26 \mathrm{~b}), 0.97(3 \mathrm{H}, \mathrm{s}$, Me-19), $0.95(3 \mathrm{H}, \mathrm{d}, J=6.2 \mathrm{~Hz}, \mathrm{Me}-27), 0.94(3 \mathrm{H}, \mathrm{d}, J=6.5 \mathrm{~Hz}, \mathrm{Me}-21)$, $0.78(3 \mathrm{H}, \mathrm{d}, J=6.6 \mathrm{~Hz}, \mathrm{Me}-28), 0.64$ (3H, s, Me-18). ${ }^{13} \mathrm{C}-\mathrm{NMR}(125 \mathrm{MHz}$, $\left.\mathrm{C}_{5} \mathrm{D}_{5} \mathrm{~N}\right) \delta: 37.3,30.2,79.2,39.2,140.8,121.8,32.1,32.0,50.3,36.8,21.2$, $39.9,42.4,56.8,24.5,28.5,56.2,11.9,19.5,36.1,19.0,34.0,31.4,34.4$, $37.8,73.9,11.9,14.7(\mathrm{C}-1-\mathrm{C}-28), 101.2,85.1,77.8,71.3,78.2,62.6(\mathrm{C}-$ $\left.1^{\prime}-\mathrm{C}-6^{\prime}\right), 106.3,76.2,76.4,81.3,76.7,62.0\left(\mathrm{C}-1^{\prime \prime}-\mathrm{C}-6^{\prime \prime}\right), 105.0,74.8$, 78.2, 71.4, 78.4, 62.4 (C-1"'-C-6"') $102.8,84.4,77.8,71.1,76.9,69.8$ (C$\left.1^{\prime \prime \prime \prime}-\mathrm{C}-6^{\prime \prime \prime \prime}\right), 106.1,76.2,76.3,81.2,76.8,62.0\left(\mathrm{C}-1^{\prime \prime \prime \prime \prime}-\mathrm{C}-6^{\prime \prime \prime \prime}\right), 105.0,74.7$, 78.2, 71.4, 78.4, $62.4\left(\mathrm{C}-1^{\prime \prime \prime \prime \prime \prime}-\mathrm{C}-6^{\prime \prime \prime \prime \prime \prime}\right), 105.3,75.1,78.4,71.5,78.4,62.5$

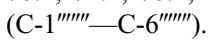

Acid Hydrolysis of 3 A solution of $\mathbf{3}(1.9 \mathrm{mg})$ was subjected to acid hydrolysis as described for $\mathbf{1}$ to give $\mathbf{3 a}(0.4 \mathrm{mg})$ and a sugar fraction $(0.4 \mathrm{mg})$. HPLC analysis of the sugar fraction under the same conditions as in the case of 1 showed the presence of D-glucose. $t_{\mathrm{R}}(\mathrm{min})$ : 13.09 (D-glucose, positive optical rotation).

Compound 4: Amorphous solid, $[\alpha]_{\mathrm{D}}^{25}-32.0^{\circ}(c=0.10, \mathrm{MeOH})$. HR-ESITOF-MS $m / z$ : $1099.5356[\mathrm{M}+\mathrm{Na}]^{+}\left(\right.$Calcd for $\left.\mathrm{C}_{52} \mathrm{H}_{84} \mathrm{O}_{23} \mathrm{Na}, 1099.5301\right)$. IR (film) $v_{\max } \mathrm{cm}^{-1}: 3375(\mathrm{OH}), 2934(\mathrm{CH}), 1724(\mathrm{C}=\mathrm{O}), 1070,1043 .{ }^{1} \mathrm{H}-$ NMR $\left(500 \mathrm{MHz}, \mathrm{C}_{5} \mathrm{D}_{5} \mathrm{~N}\right) \delta: 5.21\left(1 \mathrm{H}, \mathrm{d}, J=7.9 \mathrm{~Hz}, \mathrm{H}-1^{\prime \prime \prime}\right), 5.19(1 \mathrm{H}, \mathrm{d}$ $\left.J=7.8 \mathrm{~Hz}, \mathrm{H}-1^{\prime \prime}\right), 5.12\left(1 \mathrm{H}, \mathrm{d}, J=7.8 \mathrm{~Hz}, \mathrm{H}-1^{\prime \prime \prime \prime}\right), 5.00(1 \mathrm{H}, \mathrm{d}, J=7.9 \mathrm{~Hz}, \mathrm{H}-$ $\left.1^{\prime}\right)$. Signals for the aglycone moiety, see Table $1 .{ }^{13} \mathrm{C}-\mathrm{NMR}(125 \mathrm{MHz}$, $\left.\mathrm{C}_{5} \mathrm{D}_{5} \mathrm{~N}\right): \delta 101.6,85.1,77.7,71.2,76.9,69.8\left(\mathrm{C}-1^{\prime}-\mathrm{C}-6^{\prime}\right), 106.5,76.5$, 76.3, 81.5, 76.9, $62.2\left(\mathrm{C}-1^{\prime \prime}-\mathrm{C}-6^{\prime \prime}\right), 105.1,74.8,78.5,71.5,78.4,62.4$ (C$\left.1^{\prime \prime \prime}-\mathrm{C}-6^{\prime \prime \prime}\right), 105.4,75.2,78.2,71.6,78.5,62.7\left(\mathrm{C}-1^{\prime \prime \prime \prime}-\mathrm{C}-6^{\prime \prime \prime \prime}\right)$. Signals for the aglycone moiety, see Table 1 .

Acid Hydrolysis of 4 A solution of $4(7.1 \mathrm{mg})$ in $0.2 \mathrm{M} \mathrm{HCl}$ (dioxane- $\mathrm{H}_{2} \mathrm{O}, 1: 1,2 \mathrm{ml}$ ) was heated at $95^{\circ} \mathrm{C}$ for $1 \mathrm{~h}$ under an $\mathrm{Ar}$ atmosphere. After cooling, the reaction mixture was neutralized by passage through an Amberlite IRA-93ZU column and chromatographed on silica gel eluted with $\mathrm{CHCl}_{3}-\mathrm{MeOH}(9: 1 ; 1: 1)$ to give a sugar fraction $(2.1 \mathrm{mg})$. HPLC analysis for the sugar fraction under the same conditions as in the case of 1 showed the presence of D-glucose. $t_{\mathrm{R}}(\mathrm{min})$ : 13.01 (D-glucose, positive optical rotation).

Compound 5: Amorphous solid, $[\alpha]_{\mathrm{D}}^{25}-50.0^{\circ}(c=0.10, \mathrm{MeOH})$. HR-ESITOF-MS $m / z: 533.1244[\mathrm{M}+\mathrm{Na}]^{+}\left(\mathrm{Calcd}\right.$ for $\left.\mathrm{C}_{23} \mathrm{H}_{26} \mathrm{O}_{13} \mathrm{Na}, 533.1271\right)$. IR (film) $v_{\max } \mathrm{cm}^{-1}: 3128(\mathrm{OH}), 1704(\mathrm{C}=\mathrm{O}), 1604,1515,1464,1424$. UV $\lambda_{\max }^{\mathrm{MeOH}} \mathrm{nm}(\log \varepsilon): 283.4 \mathrm{~nm}(4.02) .{ }^{1} \mathrm{H}-\mathrm{NMR}\left(500 \mathrm{MHz}, \mathrm{CD}_{3} \mathrm{OD}\right) \delta: 7.57$ $(1 \mathrm{H}, \mathrm{d}, J=1.8 \mathrm{~Hz}, \mathrm{H}-2), 7.36(1 \mathrm{H}, \mathrm{dd}, J=8.5,1.8 \mathrm{~Hz}, \mathrm{H}-6), 7.30(2 \mathrm{H}, \mathrm{br} \mathrm{s}, \mathrm{H}-$ 2", H-6"), 7.09 (1H, d, $J=8.5 \mathrm{~Hz}, \mathrm{H}-5), 5.05\left(1 \mathrm{H}, \mathrm{d}, J=7.4 \mathrm{~Hz}, \mathrm{H}-1^{\prime}\right), 4.72$ $\left(1 \mathrm{H}, \mathrm{dd}, J=11.9,2.0 \mathrm{~Hz}, \mathrm{H}-6^{\prime} \mathrm{a}\right), 4.38$ (1H, dd, $\left.J=11.9,7.4 \mathrm{~Hz}, \mathrm{H}-6^{\prime} \mathrm{b}\right), 3.87$ (3H, s, OMe-3), $3.83\left(6 \mathrm{H}, \mathrm{s}, \mathrm{OMe}-3^{\prime \prime},-5^{\prime \prime}\right) .3 .81\left(1 \mathrm{H}, \mathrm{m}, \mathrm{H}-5^{\prime}\right), 3.56(1 \mathrm{H}, \mathrm{dd}$, $\left.J=9.1,7.4 \mathrm{~Hz}, \mathrm{H}-2^{\prime}\right), 3.52\left(1 \mathrm{H}, \mathrm{dd}, J=9.1,8.8 \mathrm{~Hz}, \mathrm{H}-3^{\prime}\right), 3.43(1 \mathrm{H}, \mathrm{dd}$ $\left.J=9.4,8.8 \mathrm{~Hz}, \mathrm{H}-4^{\prime}\right) .{ }^{13} \mathrm{C}-\mathrm{NMR}\left(125 \mathrm{MHz}, \mathrm{CD}_{3} \mathrm{OD}\right) \delta: 126.6,114.4,150.4$, 151.6, 116.3, 124.5, 169.7 (C-1-C-7), 101.8, 74.7, 77.7, 71.9, 75.8, 65.2 $\left(\mathrm{C}-1^{\prime}-\mathrm{C}-6^{\prime}\right), 121.2,108.4,149.0,142.3,149.0,108.4,167.8\left(\mathrm{C}-1^{\prime \prime}-\mathrm{C}-7^{\prime \prime}\right)$, $56.9\left(\mathrm{OMe}-3^{\prime \prime}, 5^{\prime \prime}\right), 56.6(\mathrm{OMe}-3)$.

Alkaline Methanolysis of 6 Compound $6(3.3 \mathrm{mg})$ was treated with $6 \%$ $\mathrm{NaOMe}$ in $\mathrm{MeOH}(2 \mathrm{ml})$ at room tempereture for $2 \mathrm{~h}$. The reaction mixture was neutralized by passage through an Amberrite IR-120B (Organo, Tokyo, Japan) column and chromatographed on silica gel eluted with hexane$\mathrm{Me}_{2} \mathrm{CO}(1: 2)$ to give 4-hydroxy-3,5-dimethoxybenzoic acid methyl ester $(1.2 \mathrm{mg}$ ) and $4-O-\beta$-D-glucopyranosyl-3-methoxybenzoic acid $(1.5 \mathrm{mg})$.

HL-60 Cell Culture Assay The cell growth was measured with an MTT reduction assay as described in a previous paper. ${ }^{3)}$

\section{References}

1) "Dictionary of Chinese Medicinal Materials," Vol. 2, Shanghai Scientific and Technological Press, Shanghai, 1977, pp. 1356-1357.

2) Yokosuka A., Mimaki Y., Sakagami H., Sashida Y., J. Nat. Prod., 65, $283-289$ (2002)

3) Yokosuka A., Mimaki Y., Sashida Y., Phytochemistry, 61, 73-78 (2002).

4) Yokosuka A., Mimaki Y., Sashida Y., Natural Medicines, 56, 208211 (2002).

5) Yokosuka A., Mimaki Y., Sashida Y., J. Nat. Prod., 65, 1293-1298 (2002).

6) Yokosuka A., Mimaki Y., Sashida Y., J. Nat. Prod., 66, 876-878 (2003). 
7) Yokosuka A., Mimaki Y., Sashida Y., Chem. Pharm. Bull., 52, 13961398 (2004).

8) Yokosuka A., Mimaki Y., Sakuma C., Sashida Y., Steroids, 70, 257265 (2005)

9) Malanina G. G., Klimova L. I., Morozovskaya L. M., Anisimova O. S., Arsent'ev A. G., Grinenko G. S., Khimiko-Farmatsevticheskii Zhurnal, 12, 101-105 (1978).

10) Agrawel P. K., Jain D. C., Gupta R. K., Thakur R. S., Phytochemistry, 24, 2479-2496 (1985).
11) Agrawel P. K., Phytochemistry, 31, 3307-3330 (1992).

12) Jia Z., Koike K., Nikaido T., J. Nat. Prod., 61, 1368-1373 (1998).

13) Mimaki Y., Satou T., Kuroda M., Kameyama A., Sashida Y., Li H. Y., Harada N., Chem. Lett., 1996, 431- 432.

14) Yang Q. X., Xu M., Zhang Y. J., Li H. Z., Yang C. R., Helv. Chim. Acta, 87, 1248-1253 (2004).

15) Sakushima A., Coskun M., Maoka T., Phytochemistry, 40, 257-261 (1995). 